\title{
Prediction of Spatial Distribution of Organic Carbon in Lower Brahmaputra Active Floodplain Soils of Bangladesh
}

\author{
Kamrunnahar ${ }^{1}$, Mohd. Shamsul Alam ${ }^{1}$ and Md. Saifuzzaman ${ }^{2}$ \\ ${ }^{1}$ Department of Geography and Environment, Jahangirnagar University, Savar, Dhaka 1342, Bangladesh \\ ${ }^{2}$ Department of Bioresource Engineering, McGill University, Montreal, QC, H9X 3V9, Canada \\ Manuscript received: 10 October 2020: accepted for publication: 18 January 2021
}

\begin{abstract}
Soil acts as a large reservoir of Organic Carbon (OC) but the amount varies significantly with space and time. Thus, soil analysis and interpretation of spatial variability of Soil Organic Carbon (SOC) are keys to site-specific management. The study aimed to characterize the spatial variability of SOC in an active floodplain. Soil samples were collected in three major landform categories (natural levee, back slope, marsh land) from the lower Brahmaputra River floodplain and then analyzed for SOC measurement in the laboratory. The measured data were then analyzed for spatial variability interpretation using descriptive statistics and geo-statistical analysis. The study found that the amount of SOC varies with landform variation, soil texture and distance between sample points. The topsoil of marsh land has the highest (1.41\%), back slope holds a moderate amount (1.15\%) and the natural levee has the lowest $(0.75 \%)$ amount of SOC. The amount of clay particles at the top layer was found to be positively correlated to the SOC whereas in the same layer of sand and silt showed a negative correlation. The geo-statistical analysis illustrated the nugget effect. Low $(<1 \%)$ SOC is commonly found in the agricultural soils of Bangladesh which was corroborated in this study; moderate $(1.1 \%)$ SOC was found in the floodplain. This study aimed to provide an insight into spatial variability to assist in predicting SOC in the active floodplain; consequently, the interpretation of spatial variability analysis can be implemented for site specific management strategies and to calculate carbon stock in floodplain soils.
\end{abstract}

Keywords: Soil Organic Carbon (SOC), Spatial variability, Geo-statistical analysis, Interpolated map, Site specific management

\section{INTRODUCTION}

Soil is a dynamic natural body which develops because of pedogenic natural processes during and after the weathering of rocks (Breemen and Buurman, 2002; Jenny, 1994; Nortcliff et al., 2011). It consists of mineral and organic constituents, possessing definite chemical, physical, mineralogical and biological properties which vary according to depth over the surface of the earth, and it provides a medium for plant growth (Biswas and Mukherjee, 1994; Mzuku et al., 2005). Soils are characterized by a high degree of spatial variability due to the combined effect of physical, chemical, and biological processes that operate with different intensities and at different scales (Goovaerts, 1998; Pennock and Kessel, 1997; Sağlam et al., 2011; Tan et al., 2003; Trangmar et al., 1987). Soils, in particular, are a large organic carbon (OC) reservoir with significant spatial variability (Batjes, 1996; Lal, 2004). Organic carbon in soils and sediments is widely distributed over the earth's surface occurring in almost all terrestrial and aquatic

Corresponding author: Kamrunnahar

E-mail: nishiju43@gmail.com

DOI: https://doi.org/10.3329/dujees.v8i2.54837 environments (Jobbágy and Jackson, 2000; Schnitzer and Khan, 1978). The floodplain surface and its shallow subsurface host a large reservoir for OC, including surface organic layers and soil organic carbon (Lininger et al., 20118; Perry et al., 2008).

Carbon (C) moves from the atmosphere to plants and soils and then, back in a grand cycle (Donovan, 2013) and in the context of the carbon cycle, floodplains can act as a major component of the biospheric carbon pool (Aufdenkampe et al., 1996; Battin et al., 1994). Like other soil properties, SOC levels exhibit variability because of dynamic interactions between parent material, climate, and geological history, on a regional and continental scale (Wang et al., 2001). Sanchez et al. (1997) stated that the nature and quantity of soil organic carbon affect many of the physical, chemical, and biological properties of soils. Soil $\mathrm{pH}$, buffering capacity, nutrient supplies, and the activity of soil biota are all intimately related to soil organic carbon. Due to the importance of these relationships, soil organic carbon is considered a critical component when assessing soil quality (Karlen et al. 2008).

Studies on SOC showed the highest levels of $\mathrm{C}$ at the surface horizons, decreasing quickly with 
increasing soil depths and then sometimes changing slightly after a certain depth (Wang et al. 2010). The relative distributions of SOC with soil depth have been reported globally and are known to have a strong association with topography, soil types, vegetation types, soil properties, landuse and climate (Xiao-Wei et al. 2012; Yao et al., 2010; Zhang et al. 2013). Slope and surface characteristics are major topographical parameters that control the movement of water, sediments, and nutrients, and hence, modify soil formation, soil depth, moisture status, biomass production, and C inputs (Egli et al. 2009). Yao et al. (2010) illustrated that clay provides both chemical and physical mechanisms to protect SOC from microbial decomposition.

Low SOC is a general problem in most agricultural soils of Bangladesh. More specifically, it was reported that almost $50 \%$ of the land area in Bangladesh has $<1 \%$ SOC (Karim and Iqbal, 2001) which was later supported by (Rijpma and Jahiruddin, 2004; Uddin and Rahman, 2020) who also noted that about $60 \%$ of arable land has $0.87 \%$ OC. A similar trend was observed in the case of organic matter (OM) which was reported to vary between $10 \mathrm{~g} / \mathrm{kg}$ and 17 $\mathrm{g} / \mathrm{kg}$ (Hossain, 2001) and for basin soil, organic carbon was $0.095 \mathrm{~g} / \mathrm{kg}$ (Uddin et al., 2020). The depletion of soil organic matter is reflected in low productivity which, unless addressed as a priority, may lead to a serious threat to the future sustainability of agriculture in Bangladesh. Huq and Shoaib (2013) and later Uddin et al. (2019) reported that several factors are responsible for low $\mathrm{OM}$ availability and includes intensive cropping, rapid decomposition of organic matter, deforestation, soil erosion, removal of crop residues, inundation etc. A better understanding of spatial variability of SOC is also important for refining agricultural management practices and for improving sustainable landuse. It provides a valuable base against which subsequent and future measurements can be evaluated (Liu et al., 2006).

Place-to-place variations within soil units influence floodplains study and use of soil, but this is seldom formally acknowledged in soil maps and descriptions (Campbell, 1979). This spatial information based on descriptive statistics and geostatistics allow accurate description of the floodplain soil variation (Oliver and Webster, 2015; Webster and Oliver, 1990). Kriging is commonly used as a method in spatial interpolation, after estimating semi- variogram parameters of soil properties using geostatistical tools (Goovaerts, 1998; Zhao et al. 2015; Zhao et al. 2009). Presence of accurate information about the variability of soil properties is important to apply this information in environmental predictions, appropriate farming practices, and natural resource management (Minasny et al., 2013; Mousavi et al. 2017). Given this background in the context of a floodplain, knowledge of spatial variation of soil properties is important in precision farming and environmental modelling (Breemen and Buurman, 2002).

Studies at a national scale provide generalized insights of SOC but at a local scale, uncertainty remains about the $\mathrm{OC}$ concentration in floodplain soils. It remains to be determined if it follows a predictable longitudinal variation or is controlled by local factors (Scott and Wohl, 2018). A floodplain has a landmass of different height, and the altitude controls the inundation level, vegetation type, agricultural practice, biogenic activity, and so on; all these factors are linked to the availability of SOC. Thus, it is expected that in the study area the amount/ percentage of SOC availability should reflect the heterogeneity within the floodplain with varying landform/ elevation, soil layer, soil texture and distance from the bank line. Considering these floodplain heterogeneities, this study seeks to explore the availability of SOC across the floodplain and to examine if there is any pattern to these occurrences which could be used for further predictions.

\section{MATERIALS AND METHODS}

\section{Study Site}

This study was carried out on an active floodplain (regularly flooded on a periodic basis); a portion of the lower Brahmaputra River system located in Bangladesh. The lower Brahmaputra River is braided in nature and the study floodplain belongs to the young Brahmaputra. According to Banglapedia, (2020), this young Brahmaputra floodplain comprises $5924 \mathrm{~km}^{2}$; the soil is of Gheor series (SRDI, 2003) and types are generally non-calcareous alluvium and grey in colour. They are mostly raw silty alluvium, which restricts the penetration of vegetation roots because of poor air causes aeration deficit. It has low fertility and poor moisture holding capacity (Huq and Shoaib, 2013). Figure 1 shows the location of the study area, which 
covers $39.21 \mathrm{~km}^{2}$ area of the study floodplain. The study site is characterized by a tropical monsoon climate and average annual temperature and rainfall are $25.7^{\circ} \mathrm{C}$ and $186 \mathrm{~cm}$, respectively (SRDI, 2003). The study identifies three major landforms (Figure 1) are: a) Natural levee $\left(8 \mathrm{~km}^{2}\right)$, b) Back slope $\left(27.23 \mathrm{~km}^{2}\right)$, and c) Marsh land $\left(3.97 \mathrm{~km}^{2}\right.$.

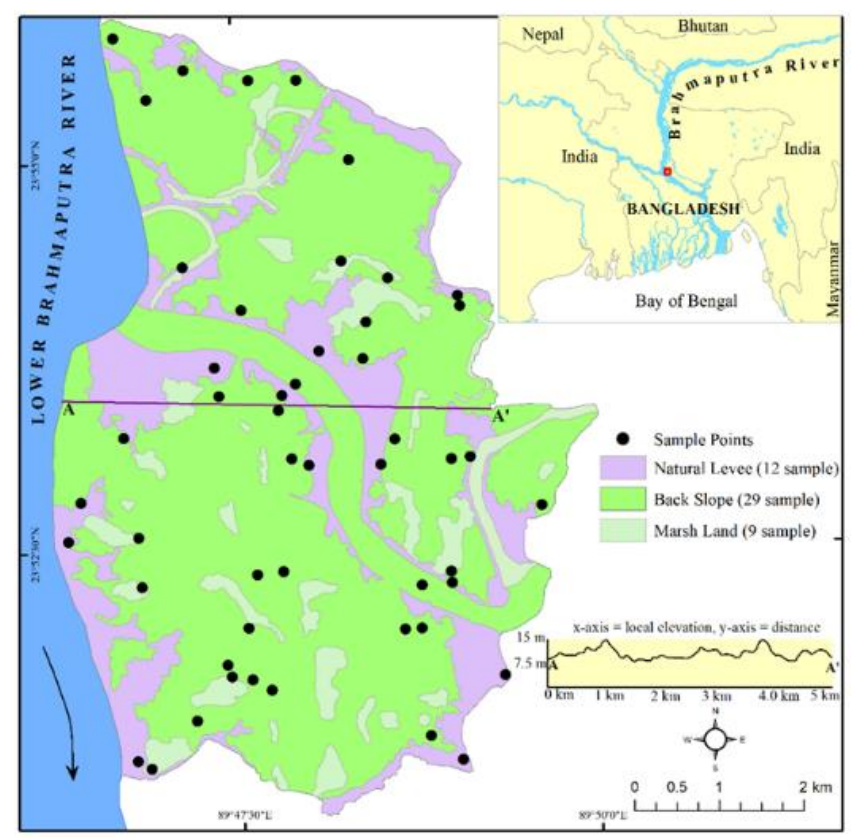

Figure 1: Study Site and Soil Sampling Location of the Lower Brahmaputra River Floodplain Along with Major Landform Types

\section{Soil Sampling and Lab Analysis}

Soil samples were collected during mid-May to early June 2019 from the study site. A systematic unaligned random sampling method was used for soil sample collection and the collected soil was mostly from agricultural land under different landform types (Figure 1). Considering the time, resources, and minimal requirements of samples for spatial prediction, it was (Figure 1) decided to collect soil samples from 50 sample points under three major landform types. For even distribution of sample numbers under each landform type, the samples were divided proportionately to the landform area. So, a total of 50 samples were collected from topsoil layer (depth $0-10 \mathrm{~cm}$ ). A soil auger was used to collect the sample from the site and the position (latitude and longitude) values of each sampling point were recorded using a Global Positioning System (GPS, accuracy $3 \mathrm{~m}$ ). The collected samples were then prepared for laboratory analysis and the amount of
SOC was measured using the Walkley and Blacks' (1934) wet oxidation method. The textural properties of soil was measured using the Hydrometer method.

\section{Data Analysis Method}

To study the relationship between SOC and the factors affecting it and to quantify the spatial distribution patterns of SOC, statistics and geostatistics have been widely applied. The data analysis conducted in two stages:

\section{Descriptive Statistics}

Distribution was analyzed by descriptive statistics (minimum, maximum, mean, median, standard deviation/SD), and the coefficient of variation/ CV. In statistical analysis $\mathrm{CV}<15 \%$ signifies low variability, $\mathrm{CV}<35 \%$ signifies moderate variability, $\mathrm{CV}>35 \%$ signifies high variability (Daniel et al., 2017). The relation between SOC and soil texture was explored using correlation analysis and then the significance of the relation was tested by Regression analysis. All the descriptive statistical analyses were conducted using Microsoft Excel 2013 software.

\section{Geostatistical Analysis}

Geostatistical parameters were calculated for each variable as a result of the corresponding semivariogram. Geostatistical analysis, including fitting the semi-variogram model and the ordinary kriging procedure, was carried out using ArcGIS (v.10.6) to assess the degree of spatial variability of each soil property used in this study. Based on the theory of a "regionalized variable" (Matheron, 1963), geo-statistics provides advanced tools to quantify the spatial features of soil parameters and to carry out spatial interpolation. Spatial structure referring to the spatial autocorrelation of field data was investigated through variogram analysis; the experimental semi-variance $\gamma(h)$ is the average of the squared variance between the pairs of field observations and is calculated using:

$\gamma(h)=\frac{1}{2 N(h)} \sum_{i=1}^{N(h)}\left[z\left(s_{i}+h\right)-z\left(s_{i}\right)\right]$

Where, $\gamma(h)$ is the predictor of experimental semivariance at distance lag $h, N(h)$ is the number of data pairs separated by distance $h, z\left(\boldsymbol{s}_{\boldsymbol{i}}\right)$ and $z\left(\boldsymbol{s}_{\boldsymbol{i}}+\boldsymbol{h}\right)$ are actual measurements of two locations separated by $h$ (Cressie, 1990).

A variogram is usually characterized by three measures- nugget, sill, and range. A variogram 
function is fitted to the experimental variogram to obtain geo-statistics, including nugget variance $(\mathrm{C} 0)$, structured variance $(\mathrm{C} 1)$, sill $(\mathrm{C} 0+\mathrm{C} 1)$, and range (A0) (Huang et al., 2015). Kriging depends on first computing an accurate variogram (Figure 4), which measures the nature of spatial dependence for the soil property (Burgess and Webster, 2019).

Degree of spatial dependence $=\frac{C 0}{C 0+C 1} \times 100 \%$

Where, nugget variance $(\mathrm{C} 0)$, structured variance (C1), sill $(\mathrm{C} 0+\mathrm{C} 1)$, and range (A0).

To explore the degree of spatial dependency, the ratio of the nugget to the sill (i.e., the nugget ratio) was calculated. According to (Huang et al., 2015) a nugget ratio $<25 \%$ indicates a strong spatial dependency; a nugget ratio $>75 \%$ indicates no spatial dependency; otherwise, the spatial dependency is moderate.

\section{RESULTS}

\section{Descriptive Statistics of SOC and Soil Texture}

Table 1 shows the descriptive statistical analysis value of SOC and soil textural properties (i.e. Sand, Silt, and Clay) of the Lower Brahmaputra River Floodplain. The minimum and maximum values of topsoil SOC were $0.19 \%$ and $1.95 \%$, respectively. CV values of all selected properties, except silt (16.98\%), showed strong variability, ranging from $40.7 \%$ for clay particle up to $150.92 \%$ for sand. The study found that the average amount of SOC for the topsoil layer is $1.1 \%$.

Table 1. Descriptive Statistical Summary (Minimum, Maximum, Median, Mean, Standard Deviation) and Coefficient of Variation of SOC and Textural Properties across the Lower Brahmaputra Active Floodplain

\begin{tabular}{|l|l|l|l|l|l|l|}
\hline $\begin{array}{l}\text { Soil } \\
\text { Properties \% }\end{array}$ & Min & Max & Median & Mean & SD & CV\% \\
\hline SOC & 0.19 & 1.95 & 1.12 & 1.1 & 0.46 & 41.58 \\
\hline Sand & 0.01 & 44.54 & 2.42 & 6.41 & 9.68 & 150.92 \\
\hline Silt & 38.49 & 85.41 & 64.61 & 63.1 & 10.71 & 16.98 \\
\hline Clay & 7.12 & 58.98 & 30.37 & 30.52 & 12.42 & 40.70 \\
\hline
\end{tabular}

Variability of SOC and Textural Properties in Different Landforms

The spatial variability of the mean amount of SOC and soil textural properties within the identified landform types across the selected floodplain topography is presented in Table 2. The study found that the amount of SOC and clay increase with decreasing land elevation while the sand and silt particles showed the opposite trend; the relationship is illustrated in Figure 2. For example, SOC of topsoil increased with decreasing elevation as it resulted in the lowest $(0.75 \%)$ mean amount in the natural levee, followed by medium $(1.15 \%)$ in the back slope and the highest $(1.41 \%)$ in the marsh-land (note that the natural levee has the highest elevation, the back slope is moderately elevated and the marsh-land lies at the lowest level). The reverse scenario is seen for sand particles as the mean amount decreased $(8.47 \%, 6.2 \%$, and $4.37 \%$ ) with waning elevation (natural levee, back slope, marsh land).

Table 2. Variability of Mean Values of Selected Soil Properties within the Identified Landform Types (Natural Levee /NL, Back Slope/BS and Marsh land/BS)

\begin{tabular}{|l|l|l|l|l|l|}
\hline $\begin{array}{l}\text { Landform } \\
\text { Types }\end{array}$ & $\begin{array}{l}\text { Number of } \\
\text { samples }\end{array}$ & SOC\% & Sand\% & Silt\% & Clay\% \\
\hline NL & 12 & 0.75 & 8.47 & 67.00 & 24.51 \\
\hline BS & 29 & 1.15 & 6.2 & 63.17 & 30.64 \\
\hline ML & 9 & 1.41 & 4.37 & 57.46 & 38.17 \\
\hline
\end{tabular}

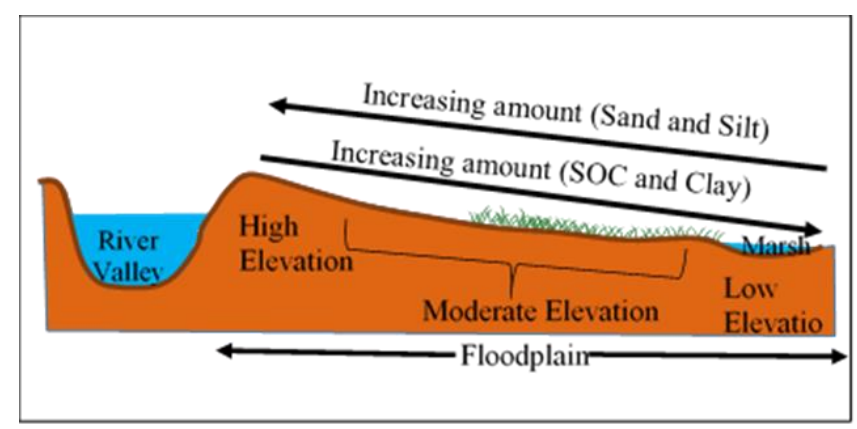

Figure 2: Land Elevation Controls the Variation of SOC in Floodplain. High Elevated Area Possess Low SOC due to Low Clay and High Sand While Low Lying Area Does the Opposite

\section{Spatial Relation between SOC and Soil Textural Properties}

Following is the correlation (r) matrix table (Table 3) of SOC, Pearson correlation coefficient. The topsoil and subsoil SOC showed high strong positive correlation $(r=0.69)$. Among textural properties, only the clay particle resulted in a positive correlation with both topsoil $(r=0.63)$ and subsoil $(r=0.28)$ SOC while all other (i.e. sand, silt) properties are negatively correlated with each other. There is a strong negative correlation between the silt and clay particles $(r=-$ $0.66)$ and moderate for topsoil SOC and clay $(r=$ $0.47)$ and Clay and sand particles $(r=-0.55)$. There is 
a weak to extremely weak/ no relation between topsoil textural properties and subsoil SOC.

Table 3. The Correlation Matrix Calculated through Pearson's Correlation r of Selected Soil Properties

\begin{tabular}{|l|l|l|l|l|}
\hline \multicolumn{1}{|c|}{ Soil Properties } & SOC $\%$ & Sand $\%$ & Silt $\%$ & Clay \% \\
\hline SOC\% & 1 & & & \\
\hline Sand $\%$ & $-0.47^{* *}$ & 1 & & \\
\hline Silt $\%$ & $-0.31^{*}$ & -0.26 & 1 & \\
\hline Clay\% & $0.63^{* *}$ & $-0.55^{* *}$ & $-0.66^{* *}$ & 1 \\
\hline
\end{tabular}

$*$ presenting $\mathrm{p}<0.05$ and $* *$ presents $\mathrm{p}<0.01$. The value of $\mathrm{p}$ is obtained by regression analysis.

\section{Spatial Variability of SOC}

Maps derived from the geo-statistical kriging method are presented in Figure 4 showing predicted spatial variation of topsoil SOC. A spherical model was used to calculate the variogram for SOC, as it fitted for both topsoil SOC. Figure 3 presents the fitted variogram graph of SOC.

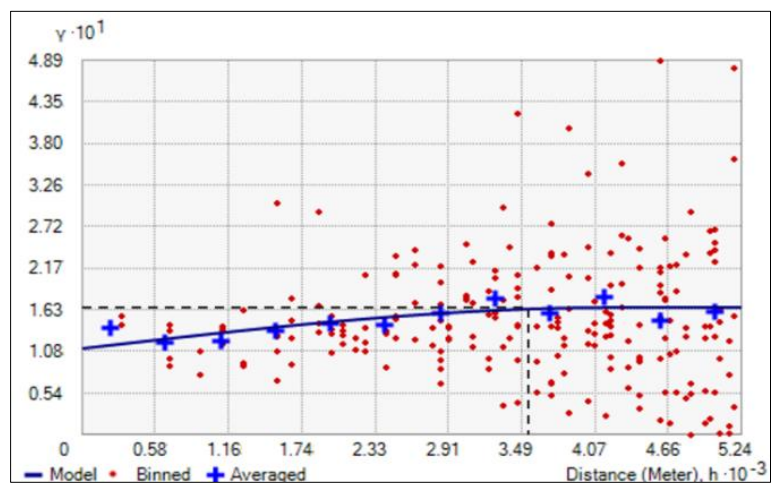

Fig. 3. Fitted Variogram Graph of SOC $(0-10 \mathrm{~cm})$ in Which the $\mathrm{x}$ - axis is Lag Distance $(\mathrm{h})$ and on the $\mathrm{y}$-Axis is SemiVariance $\hat{\gamma}$.

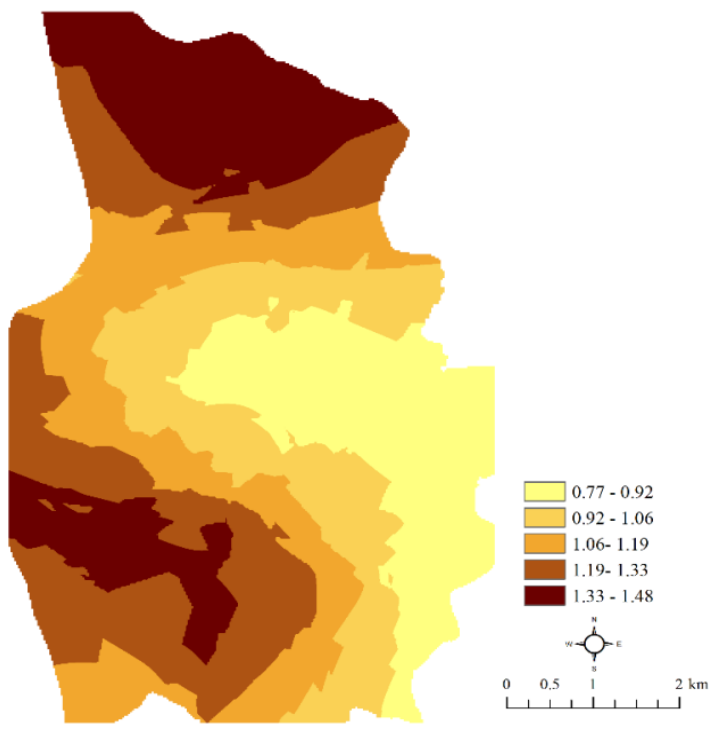

Figure 4: Krigged Maps of SOC $(0-10 \mathrm{~cm})$ of Lower Brahmaputra Active Floodplain. Predicted Map Presents More Diversity and Area with High to Moderate SOC.

Variogram of topsoil SOC show the nugget effect (0.13) and moderate spatial dependence (59.09) where spatial dependence is calculated from nugget $(0.13)$ and sill (0.09). The lag distance for measured variogram was $670.46 \mathrm{~m}$. The Root Mean Square Error (RMSE) was found low (0.43) from predictions variogram. The results indicate that topsoil SOC covered a high range $4224.09 \mathrm{~m}$. The prediction map reflected the effect of landform variation as the high predicted SOC cluster around low elevated area and low SOC near high elevated land area.

\section{DISCUSSION}

The primary finding of the study is that there exists heterogeneity in the distribution of SOC throughout the floodplain with varying conditions, thus, the hypothesis is accepted. The results showed that there exist strong variability $(\mathrm{CV})$ for most of the properties, considering topographic variations or variations in soil depth or among the selected soil properties. The average amount of SOC in the study floodplain found moderate (1.1\%) which is a common phenomenon for the soils of Bangladesh as described in the introduction. Results showed that there is an inverse relationship between land level and SOC, with decreasing land level (Natural levee to marsh land) the amount of SOC increases. Shelukindo et al. (2014) determined that topography modifies overall climatic conditions and sediment deposition which affect the decomposition, accumulation, and formation of SOC in the floodplain.

The textural properties were included in the study as they are a direct controlling factor of SOC concentration in a floodplain. In this study area, it was found that soils fall under 6 different textural classes and the amount of sand, silt, clay varies at the intense range (very low to very high). Huq and Shoaib (2013) described tidal and estuarine floodplains containing low sand $(<5 \%)$ compared to meandering floodplains, while this study had a braided river floodplain containing very low $(<1 \%)$ amounts of sand, especially in agricultural soils. The results also presented a strong positive correlation $(r=0.63)$ between SOC and clay, which is statistically significant $(p<.05)$; the reason behind this might be due to the formation of clay-organic complex. 
Spatial dependency that predicted the spatial variation of SOC was the main focus of the study. The geo-statistical analysis resulted in a long-range dependency for SOC (variogram range A0 $>400 \mathrm{~m}$ ) which reflects the topographic variation as confirmed earlier by Liu et al. (2013). The prediction map of topsoil SOC (Figure 4) indicates a high concentration of SOC on the southwestern and midwestern part of the floodplain which is acceptable because the area is mostly low lying facilitating the accumulation of SOC. The study considered the local variation of land level/altitude which was considered during soil sampling as it is the most important factor influencing SOC concentration. The relation between SOC and land level is reflected in the predicted maps.

\section{CONCLUSIONS}

The active floodplain has a distinct environmental setting and provides a suitable condition for OC generation. In the study area, the available volume of SOC is slightly higher $(1.1 \%)$ than the national average $(<1 \%)$ but the difference is not an outlier. The available amount of SOC in the floodplain is moderate and the spatial dependence is also moderate. Local factors, land level variations and textural variations are appeared to be very closely related to SOC concentration in the studied floodplain soils. The study tried to provide a comprehensive characterization of the distribution of SOC and its spatial prediction in an active floodplain at the local scale. This prediction approach can be used in farmlevel/site-specific agricultural practices such as a better understanding of the concentration of SOC, agricultural zoning, or grading the use of fertilizer or calculation of the carbon stocks.

In this study, it was not possible to incorporate the relationship between subsoil SOC and textural properties. Furthermore, with other influential factors (e.g., organisms, time, vegetation type, soil chemical properties etc.) affecting SOC concentrations were not determined. Thus, there remains scope for further study on floodplain SOC and its distribution in space. Besides, there are limited studies on the spatial variability of SOC within and among different floodplain soils of Bangladesh at a local scale. This research makes an important contribution to studies related to the prediction of floodplain soils and agricultural management strategies.
ACKNOWLEDGEMENT: This work was supported by the Special allocation of the Ministry of Science and Technology, Government of Bangladesh (Grant no. 2019-06/399). Authors are grateful to Soil and Environment Laboratories of Bangladesh Council of Scientific and Industrial Research (BCSIR). M. Ali, A. Hoque, and M. Hasan Rifat are also thanked for field sample collection. Data for the research project were supported by Bangladesh Agricultural Research Council and Soil Resource Development Institute (SRDI), Bangladesh.

\section{REFERENCES}

Aufdenkampe, A.K., Mayorga, E., Raymond, P.A., Melack, J.M., Doney, S.C., Alin, S.R., Aalto, R.E. and Yoo, K. (2011). Riverine coupling of biogeochemical cycles between land, oceans, and atmosphere. Frontiers in Ecology and the Environment, 9:53-60. https://doi.org/10.1890/100014

Batjes, N.H. (1996). Total carbon and nitrogen in the soils of the world. Eur. J. Soil Sci., 65:10-21. https://doi.org/10.1111/ejss.12114_2

Battin, T.J., Luyssaert, S. Kaplan, L.A., Aufdenkampe, A.K., Richter, A. and Tranvik, L.J. (2009). The boundless carbon cycle. Nature Geosci., 2:598-600. https://doi.org/10.1038/ngeo618

Biswas, T. D. and Mukherjee, S. K. (1994). Textbook of Soil Science. Tata McGraw-Hill Publishing Company Limited, New Delhi.

Breemen, V., and Buurman, P. (2002). Soil Formation. Springer Netherlands, Dordrecht. https://doi.org/10.1007/978-0-585-31788-5.

Burgess, T.M. and Webster, R. (2019). Optimal interpolation and isarithmic mapping of soil properties: I The semi-variogram and punctual kriging. Eur. J. Soil Sci., 70:11-19. https://doi.org/10.1111/ejss. 12784

Campbell, J.B. (1979). Spatial Variability of Soils. Annals of the Association of American Geographers, 69: $\quad 544-556 . \quad$ https://doi.org/10.1111/j.14678306.1979.tb01281.x

Cressie, N. (1990). The origins of kriging. Mathematical Geology, 22: 239-252.

Daniel, S., Gabiri, G., Kirimi, F., Glasner, B., Näschen, K., Leemhuis, C., Steinbach, S. and Mtei, K. (2017). Spatial Distribution of Soil Hydrological Properties in the Kilombero Floodplain, Tanzania. Hydrology, 4: 57. https://doi.org/10.3390/hydrology4040057

Donovan, P. (2013). Measuring soil carbon change: a flexible, practical, local method. https://soilcarboncoalition.org/files/ Measuring Soil Carbon Change.pdf. 
Egli, M., Sartori, G., Mirabella, A., Favilli, F., Giaccai, D., Delbos, E. (2009). Effect of north and south exposure on organic matter in high Alpine soils. Geoderma, 149:124-136. https://doi.org/10.1016/j.geoderma.2008.11.027

Floodplain. (n.d.). (2020). Banglapedia. Retrived January 14, from http://en.banglapedia.org/index.php? title=Floodplain (accessed 1.14.20).

Goovaerts, P. (1998). Geostatistical tools for characterizing the spatial variability of microbiological and physico-chemical soil properties. Biology and Fertility of Soils, 27:315-334. https://doi.org/10.1007/s003740050439

Hossain, Z. (2001). Farmer's view on soil organic matter depletion and its management in Bangladesh. Nutrient Cycling in Agroecosystems J., 61:197-204. https://doi.org/10.1007/978-94-017-2172-1_18

Huang, Y., Wang, Y., Zhao, Y., Xu, X., Zhang, J. and Li, C. (2015). Spatiotemporal Distribution of Soil Moisture and Salinity in the Taklimakan Desert Highway Shelterbelt. Water, 7:4343-4361. https://doi.org/10.3390/w7084343

Huq, S. M. I. and Shoaib, J. U. M. (2013). The Soils of Bangladesh, World Soils Book Series. Springer Netherlands, Dordrecht. https://doi.org/10.1007/97894-007-1128-0

Jenny, H. (1994). Factors of soil formation: a system of quantitative pedology, Dover, New York.

Jobbágy, E.G.and Jackson, R.B. (2000). The Vertical Distribution of Soil Organic Carbon and its Relation to Climate and Vegetation. Ecological Applications, 10:423-436. https://doi.org/10.1890/10510761(2000) 010[0423:TVDOSO]2.0.CO;2

Karim, Z. and Iqbal, A. (2001). Impact of land degradation in Bangladesh: Changing scenario in agricultural land use. Soils Division, Bangladesh Agricultural Research Council.

Karlen, D. L., Andrews, S. S., Wienhold, B. J. and Zobeck, T. M. (2008). Soil Quality Assessment: Past, Present and Future. J. Integr. Biosci., 6:03-14.

Lal, R. (2004). Soil Carbon Sequestration Impacts on Global Climate Change and Food Security. Science, 304:1623-1627.

https://doi.org/10.1126/science.1097396

Lininger, K.B., Wohl, E. and Rose, J.R. (2018). Geomorphic Controls on Floodplain Soil Organic Carbon in the Yukon Flats, Interior Alaska, From Reach to River Basin Scales. Water Resour. Res.,
54:1934-1951. https://doi.org/10.1002/2017WR022042

Liu, D., Wang, Z., Zhang, B., Song, K., Li, X., Li, J., Li, F. and Duan, H. (2006). Spatial distribution of soil organic carbon and analysis of related factors in croplands of the black soil region, Northeast China. Agriculture, Ecosystems \& Environment, 113:73-81. https://doi.org/10.1016/j.agee.2005.09.006

Liu, Y., Lv, J., Zhang, B. and Bi, J. (2013). Spatial multi-scale variability of soil nutrients in relation to environmental factors in a typical agricultural region, Eastern China. Science of the Total Environment, 450 451:108-119.

https://doi.org/10.1016/j.scitotenv.2013.01.083

Minasny, B., McBratney, A.B., Malone, B.P. and Wheeler, I. (2013). Digital Mapping of Soil Carbon, in: Advances in Agronomy. Elsevier, pp. 1-47. https://doi.org/10.1016/B978-0-12-405942-9.00001-3

Mousavi, S.R., Sarmadian, F., Dehghani, S., Sadikhani, M.R. and Taati, A. (2017). Evaluating inverse distance weighting and kriging methods in estimation of some physical and chemical properties of soil in Qazvin Plain. Eurasian Journal of Soil Science (EJSS), 6:327336. https://doi.org/10.18393/ejss.311210

Mzuku, M., Khosla, R., Reich, R., Inman, D., Smith, F. and MacDonald, L. (2005). Spatial Variability of Measured Soil Properties across Site-Specific Management Zones. Soil Sci. Soc. Am. J., 69:15721579. https://doi.org/10.2136/sssaj2005.0062

Nortcliff, S., Hulpke, H., Bannick, C.G., Terytze, K., Knoop, G., Bredemeier, M. and Schulte-Bisping, H. (2011). Soil, Definition, Function, and Utilization of Soil, in: Wiley-VCH Verlag GmbH \& Co. KGaA (Ed.), Ullmann's Encyclopedia of Industrial Chemistry. Wiley-VCH Verlag GmbH \& Co. KGaA, Weinheim, Germany, p. b07_613.pub3.

https://doi.org/10.1002/14356007.b07_613.pub3

Oliver, M.A. and Webster, R. (2015). Basic Steps in Geostatistics: The Variogram and Kriging, Springer Briefs in Agriculture. Springer International Publishing, Cham, https://doi.org/10.1007/978-3-319-15865-5

Pennock, D.J. and Kessel, C. van. (1997). Effect of agriculture and of clear-cut forest harvest on landscapescale soil organic carbon storage in Saskatchewan. Can. J. Soil. Sci., 77:.211-218. https://doi.org/10.4141/S96-112

Perry, D.A., Oren, R. and Hart, S.C. (2008). Forest ecosystems, 2nd ed. ed. Johns Hopkins University Press, Baltimore. 
Rijpma, J. and Jahiruddin, M. (2004). Strategy and Plan for use of soil nutrient balance in Bangladesh. Final Report of Short-term Assignment. SFFP/DANIDA.

Sağlam, M., Öztürk, H.S., Erşahin, S. and Özkan, A.İ. (2011). Spatial variation of soil physical properties in adjacent alluvial and colluvial soils under Ustic moisture regime. Hydrol. Earth Syst. Sci. Discuss., 8:4261-4280. https://doi.org/10.5194/hessd-8-42612011

Sanchez, P. A., Buresh, R. J. and Leakey, R. R. B. (1997). Trees, soils, and food security. Philosophical Transactions of The Royal Society, 352:949-961. https://doi.org/10.1098/rstb.1997.0074

Santra, P., Chopra, U.K. and Chakraborty, D. (2008). Spatial variability of soil properties and its application in predicting surface map of hydraulic parameters in an agricultural farm. Current Science, 95: 9.

Schnitzer, M. and Khan, S.U. (Eds.) (1978). Soil organic matter, Developments in soil science. Elsevier Scientific Pub. Co., distributors for the U.S. and Canada, Elsevier/North-Holland, Amsterdam ; New York.

Scott, D.N. and Wohl, E.E. (2018). Geomorphic regulation of floodplain soil organic carbon concentration in watersheds of the Rocky and Cascade Mountains, USA. Earth Surf. Dynam., 6:1101-1114. https://doi.org/10.5194/esurf-6-1101-2018

Shelukindo, H. B., Semu, E., Msanya, B. M., Munishi, P. K. T., Maliondo, S. M. S. and Singh, B. R. (2014). Potential of carbon storage in major soil types of the Miombo woodland ecosystem, Tanzania: A review. American Open Journal of Agricultural Research, 2:121.

SRDI (Soil Resource Development Institute). (2003). The Land and Soil Resources Utilization Guide. Soil Resources Development Institute, Government of the People's Republic of Bangladesh, Dhaka, Bangladesh.

Tan, Z.X., Lal, R., Smeck, N.E., Calhoun, F.G., Gehring, R.M. and Parkinson, B. (2003). Identifying associations among soil and site variables using canonical correlation analysis. Soil Science, 168:376$382 . \quad$ https://doi.org/10.1097/01.ss.0000070912. 55992.d5

Trangmar, B.B., Yost, R.S., Wade, M.K., Uehara, G. and Suojadi, M. (1987). Spatial Variation of Soil Properties and Rice Yield on Recently Cleared Land. Soil Sci. Soc. Am. J., 51: 8.

Uddin, M. J., Rahman, A., Ali, A.H.M. Z. and Rahman. Md. K. (2020). Estimation of Carbon Stockin the Sylhet
Basin Soils of Bangladesh. Journal of the Asiatic Society of Bangladesh Science, 46(1):49-60.

Uddin, M.J., Hooda, P.S., Mohiuddin, A.S.M., Smith, M., and Aller M. (2019). Land Inundation and Cropping Intensity influences on Organic Carbon in the Agricultural Soils of Bangladesh. Catena, 178: 11-19.

Walkley, A.J. and Black, I.A. (1934). Estimation of soil organic carbon by the chromic acid titration method. Soil Sci. 37:29-38.

Wang, J., Fu, B., Qiu, Y. and Chen, L. (2001). Soil nutrients in relation to land use and landscape position in the semi-arid small catchment on the loess plateau in China. Journal of Arid Environments, 48:537-550. https://doi.org/10.1006/jare.2000.0763

Wang, Z.-M., Zhang, B., Song, K.-S., Liu, D.-W. and Ren, C.-Y. (2010). Spatial Variability of Soil Organic Carbon under Maize Monoculture in the Song-Nen Plain, Northeast China. Pedosphere, 20:80-89. https://doi.org/10.1016/S1002-0160(09)60285-X

Webster, R., and Oliver, M. A. (1990). Statistical methods in soil and land resource survey. Oxford Oxford University Press (OUP).

Xiao-Wei, C., Huang, X.-J., Wang, W.-J., Zhang, M., Lai, L. and Liao, Q.-L. (2012). Spatial Variability of Soil Organic Carbon and Related Factors in Jiangsu Province, China. Pedosphere, 22(3):404-414. https://doi.org/10.1016/S1002-0160(12)60026-5

Yao, M.K., Angui, P.K.T., Konaté, S., Tondoh, J.E., Tano, Y., Abbadie, L. and Benest, D. (2010). Effects of Land Use Types on Soil Organic Carbon and Nitrogen Dynamics in Mid-West Côte d'Ivoire. European Journal of Scientific Research, 40:211-222.

Zhang, C., Liu, G., Xue, S. and Sun, C. (2013). Soil organic carbon and total nitrogen storage as affected by land use in a small watershed of the Loess Plateau, China. European Journal of Soil Biology, 54:16-24. https://doi.org/10.1016/j.ejsobi.2012.10.007

Zhao, C., Dong, S., Liu, S., Sylvie, I., Li, J., Liu, Q. and Wang, C. (2015). Spatial distribution and environmental risk of major elements in surface sediments associated Manwan Dam in Lancang River, China. Eurasian Journal of Soil Science (EJSS), 4:22. https://doi.org/10.18393/ejss.37849

Zhao, Y., Xu, X., Darilek, J.L., Huang, B., Sun, W. and Shi, X. (2009). Spatial variability assessment of soil nutrients in an intense agricultural area, a case study of Rugao County in Yangtze River Delta Region, China. Environ. Geol., 57:1089-1102. https://doi.org/10.1007/s00254-008-1399-5 
